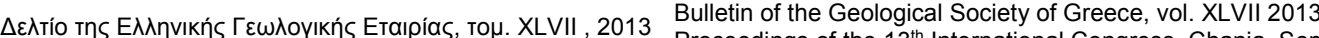

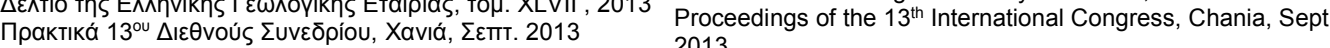
2013

\title{
ASSESSMENT OF HEAVY METALS CONTAMINATION IN THE COASTAL SEDIMENTS OF THE BROADER AREA OF CHIOS HARBOR (AEGEAN SEA)
}

\author{
Tsoutsia A. ${ }^{1}$, Kapsimalis V. ${ }^{2}$, Poulos $\underset{\text { E. }}{S .}{ }^{1}$ Paraskevopoyloy $V .{ }^{3}$ and Dassenakis \\ ${ }^{1}$ University of Athens, Faculty of Geology and Geoenvironment, Department of Geography \& \\ Climatology, Panepistimioupoli, Zografou 15784, Athens, Greece \\ ${ }^{2}$ Hellenic Centre for Marine Research (HCMR), Institute of Oceanography, $46.7^{\text {th }} \mathrm{km}$ Athens - \\ Sounio Ave., P.O Box 712, P.C. 19013, Anavyssos, Greece \\ ${ }^{3}$ University of Athens, Faculty of Chemistry, Laboratory of Environmental Chemistry, \\ Panepistimioupolis-Zografou, 15784, Greece.
}

\begin{abstract}
The present study evaluates the pollution level of the surficial sediments of the coastal area around the city of Chios (east Aegean Sea), with particular emphasis on the Port of Chios, fishing shelters, the waste water treatment plant and the electric power plant. For this reason, the metals/trace metals ( $\mathrm{Pb}, \mathrm{Fe}, \mathrm{Zn}, \mathrm{Cu}, \mathrm{Cr}$, $\mathrm{Mn}, \mathrm{Al}$, Ni) along with total organic carbon (TOC) and $\mathrm{CaCO}_{3}$ were analyzed in 23 sediment samples. The results showed that the highest concentrations are observed in the main Port, offshore the power plant station and in a small fishing shelter, without being considered as dangerous for the marine organisms and human health, according to metal pollution indices and Sediment Quality Guidelines.
\end{abstract}

Key words: trace metals, seabed sediments' pollution, Chios Island, North Aegean.

\section{Пврі́ $\eta \psi \eta$}

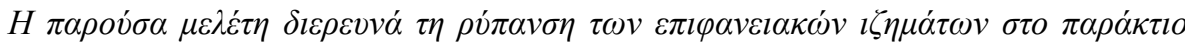

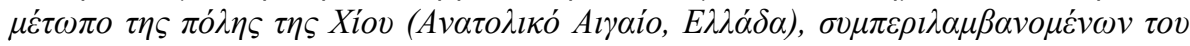

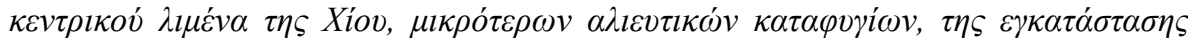

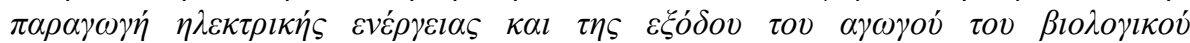

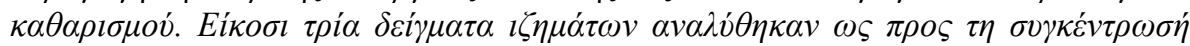

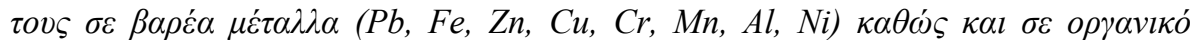

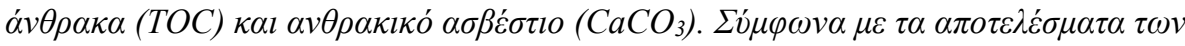

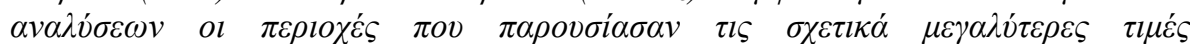

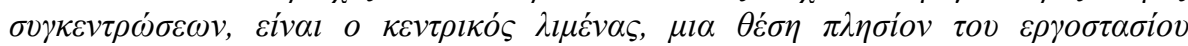

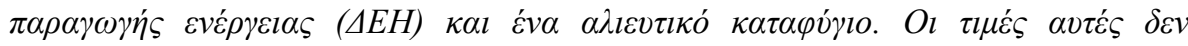

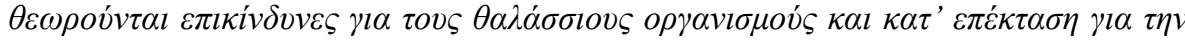

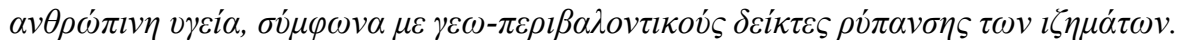

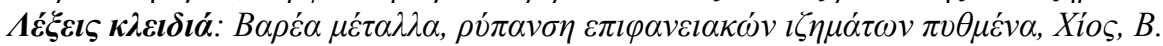
Alyaio. 


\section{Introduction}

Marine pollution may be related to natural factors (e.g. increased concentration of various chemical and radioactive elements, ash) and to a variety of human activities (e.g. industry, marine transport, oil spills, untreated sewage, agriculture). The main categories of marine pollution are (Clark, 1993): (1) organic contaminants, which cause the reduction of dissolved oxygen; (2) increased nutrient content; (3) microbial pollution; (4) oil pollution; (5) pollution by halogenated hydrocarbons; (6) solid waste (garbage); (7) heavy metals; (8) radiation; and (9) thermal pollution.

The effects of heavy metal pollution to aquatic life can be estimated by: (a) the application of a variety of geostatistical indices, such as the Geoaccumulation Index (Igeo) (Muller, 1969; Fốrstner et al., 1990), the Combined Contamination Index (W) (Widianarko et al., 2000), the Modified Contamination Degree (mCd) (Abrahim and Parker, 2008); and (b) the comparison with effectbased numerical Sediment Quality Guidelines (SQG), which provide tolerable concentrations of sediment-bound contaminants in order to protect the organisms living in or near sediments. The most common set of SQGs is the ERL/ERM approach (Long et al., 1995) that provides: (i) a lower threshold value (ERL: Effect Range Low) below which adverse effects on sensitive life stages and/or species occurred only infrequently and (ii) an upper threshold value (ERM: Effect Range Median) above which adverse effects were frequently observed.

The purpose of the present investigation is to assess the degree of heavy metal contamination in surface sediments of the coastal zone of the city-harbour of Chios Island. Particular attention is given to locations with intense human activities, such as the Commercial harbour of Chios, fishing shelters and coastal areas in the vicinity of industrial plants, in order to identify the potential sources of pollution. In addition, the probable adverse effects of sediments to aquatic organisms were assessed through the application of widely used sediment pollution indices and quality guidelines.

\section{The Study Area}

Chios Island lies in the Eastern Aegean Sea (Fig. 1) and geologically belongs to the Pelagonian isotopic zone. Lithologically, the NE - SW Chios consists of limestones and dolomites (middle Triasic or Triassic to Lower Jurassic in age) its NW part of schists, grauwackes, conglomerates with lenses of limestone (Paleozoic), while its ESE part comprises of marl, clay rocks, limestones and sandstones (lower Miocene - lower Pliocene) (Bornovas and Rondogianni -Tsiambaou, 1989). The wave climate (Tsoutsia, 2012) of the narrow passage between the east coast of Chios and the Asia Minor (Turkey) is characterized by a moderate wave regime with the north waves to be the dominant $(21.9 \%$, annually) ones. The most frequently occurring north waves $(4.4 \%)$ have significant wave height of only $0.2 \mathrm{~m}$ and period $0.2 \mathrm{sec}$. On the other hand, the highest observed waves are the easterly ones having significant heights $<5 \mathrm{~m}$ and period $<8 \mathrm{sec}$, but occurring very rarely $(<0.01 \%)$. Parthenis and Kokkalas are the main rivers debouching in the study area; the former covers an area of $23.7 \mathrm{~km}^{2}$, reaching the $800 \mathrm{~m}$ in altitude, while the latter drains an area of $36.3 \mathrm{~km}^{2}$, being in altitude up to $707 \mathrm{~m}$ (Paidas, 2011). In addition, along the east coast of the Chios Island few ephemeral streams debouch also. The main human activities with significant potential to pollute coastal environment are the harbour and the Electric Power Plant (Fig. 2).

\section{Materials and Methods}

The present investigation is based on the granulometric and geochemical analyses of 23 samples, which were collected in October of 2011 with the use of a van Veen grab. The grain size treatment included: (a) wet separation of the bulk sample through a $63 \mu \mathrm{m}$ sieve; (b) dry sieving of the coarse-grained fraction (particle size $>63 \mu \mathrm{m}$ ); and (c) laser diffraction analysis of the fine-grained fraction (particle size $<63 \mu \mathrm{m}$ ) using a Malvern Mastersizer 2000.

$\underline{\text { XLVII, No } 3-1582}$ 

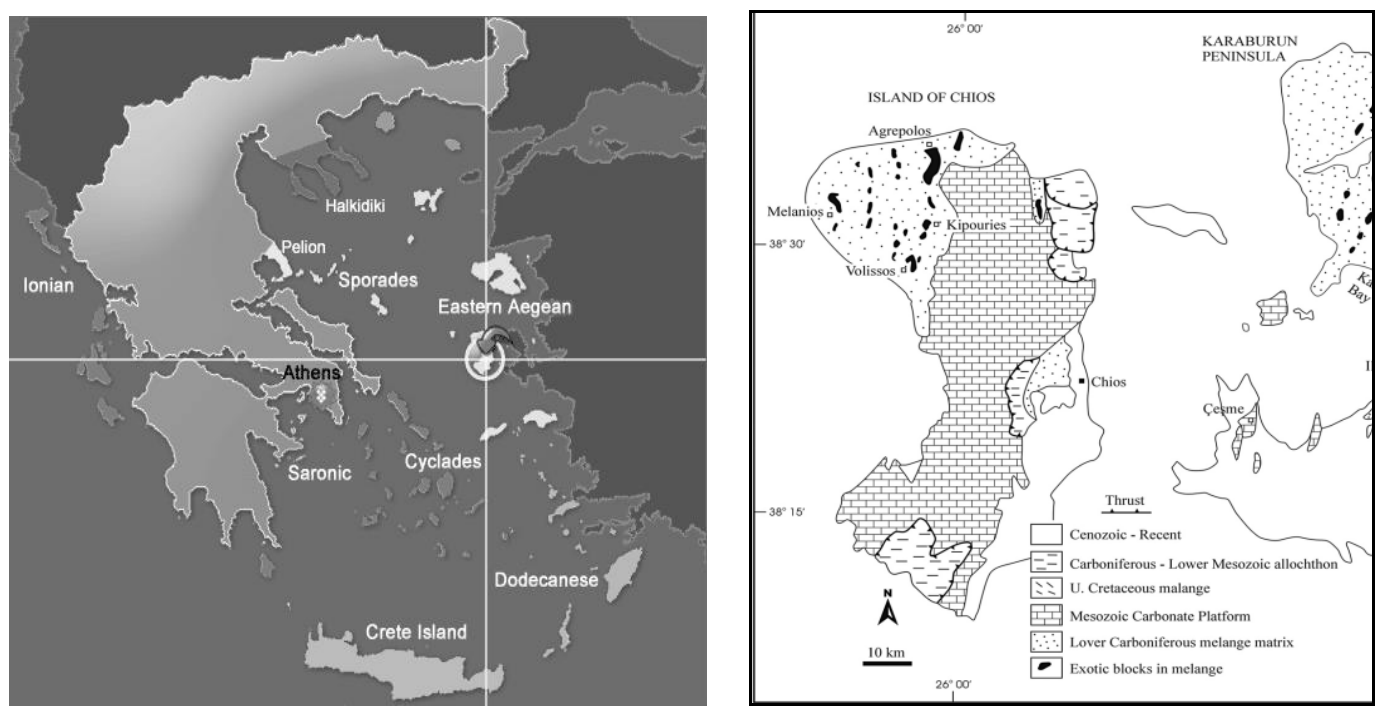

Figure 1 - Location of Chios Island (left); Simplified lithological map of Chios Island (right) (abstracted from Robertson \& Ustaömer, 2009).

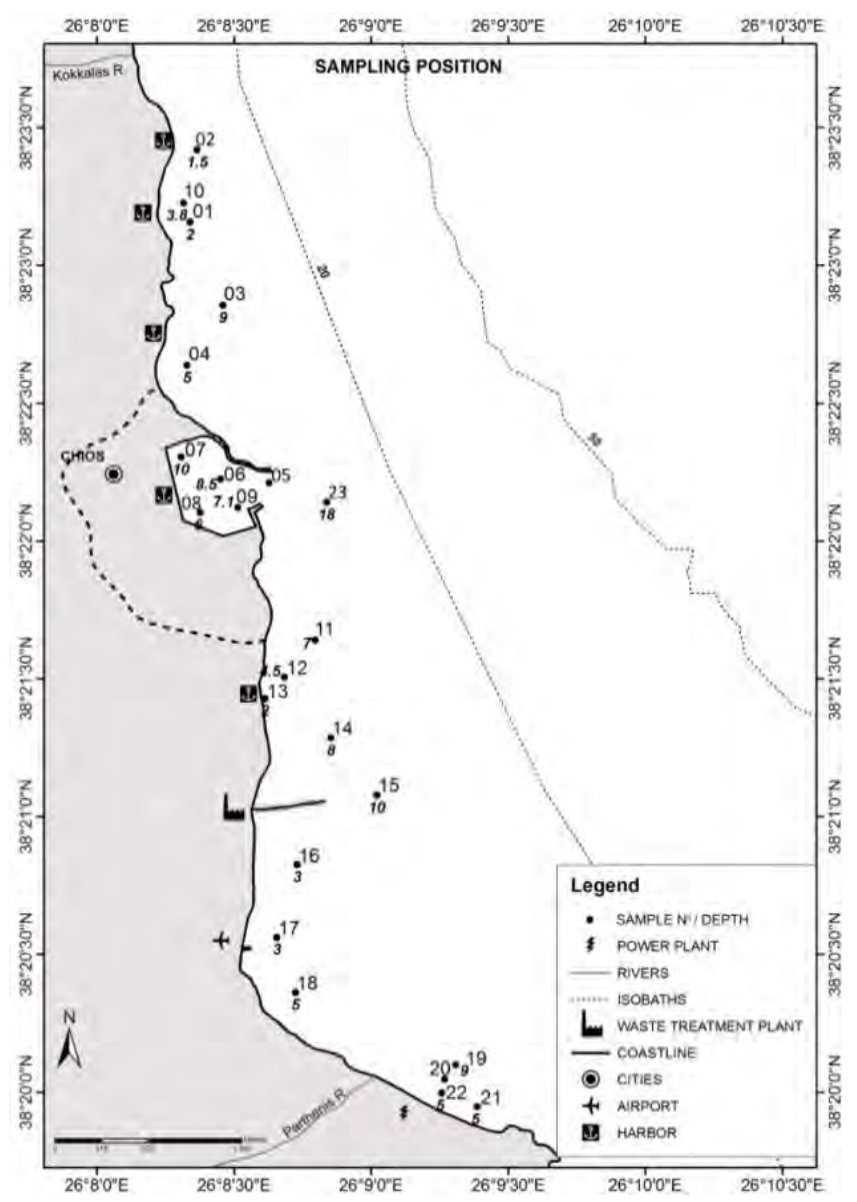

Figure 2 - The coastal area under investigation together with sampling locations and major human activities.

$\underline{\text { XLVII, No } 3-1583}$ 
The concentrations of major ( $\mathrm{Al}$ and $\mathrm{Fe}$ ) and trace $(\mathrm{Cr}, \mathrm{Cu}, \mathrm{Mn}, \mathrm{Ni}, \mathrm{Pb}$ and $\mathrm{Zn}$ ) elements (in the dry weight) were determined both in the bulk sample and in the fine-grained fraction (when its content was more than $10 \%$ of the total sample) using a Graphite Furnace Atomic Absorption

(GF-AAS) and/or Flame Atomic Absorption (FAAS). The organic Carbon content was estimated in accordance to Walkey and Black (1934) method, while the carbonate concentration was calculated after treatment of each sample with solution of HCL $6 \mathrm{M}$ of each sample and with the use of the following equation:

\section{Equation 1}

$\%$ Carbonates $=\frac{m_{1}-m_{2}}{m_{s}}$

where: $\mathrm{m}_{1}$ : mass before treatment; $\mathrm{m}_{2}$ mass after 1.5 minute treatment and $\mathrm{m}_{\mathrm{s}}$ : total sediment mass.

The indices that were used to describe the environmental status were: Igeo (Geoaccummulation index, after Muller (1969) and Förstner et al. (1990)); mCd (modified Contamination degree, after Abrahim and Parker (2008)); and W (combined contamination index, after Abrahim and Parker (2008)).

\section{Equation 2}

$$
\operatorname{Igeo}=\log _{2}\left(\frac{c_{i}}{1.5 B_{i}}\right)
$$

where: $c_{i}$ : the concentration of element in the sediment and $\mathrm{B}_{\mathrm{i}}$ : the concentration of element in the reference sediment.

\section{Equation 3}

$$
m C d=\frac{\sum_{i=1}^{n} c f_{i}}{n}
$$

where: n: number of analyzed samples ( $\Sigma$ : algebraic sum), $c f$ : the contamination factor.

\section{Equation 4}

$$
W=\log \prod_{i} c f_{i}
$$

where: $c f$ : values of the ratios of concentrations of heavy metals in sediment samples with the corresponding present in natural sediment reference (where $\Pi$ : the algebraic product).

The incidence of adverse biological effects was investigated utilizing the ERM (Effects Range Low), ERL (Effects Range Median), (Long et al., 1995), and TEL (Threshold Effects Level), PEL (Probable Effects Level) (Macdonald et al., 1996) guidelines values that are associated with ranges of trace metal chemical concentrations; the latter are provided by Macdonald et al. (1996; table 3 p. 266) and by Long et al. (1995; table 3 p. 92), respectively.

\section{Results and Discussion}

The sand fraction varies from $17.94 \%$ (sample 13) to $99.98 \%$ (sample 17), with samples 1 (99.59\%), 12 (98.31\%), 17 (99.98\%) and 21 (99.05\%) exceeding the 98\% (Table 1); samples 4 $(21.20 \%), 9(21.45 \%)$ and $13(17.94 \%)$ consists of $<25 \%$ of sand, whereas the average value of sand is equal to $52.74 \%$. Silt varies from $0.00 \%$ (sample 22 ) to $62.13 \%$ (sample 4 ), having an 
average value of $31.85 \%$. Clay, having smaller contributions, varies from $0 \%$ (samples: $1,12,17$, $20,21 \& 22$ ) up to $20.18 \%$ (sample 7), with an average value of $9.58 \%$. According to Folk (1974), most of the samples are characterized as slightly sandy mud (s)M.

In terms of heavy metals, the average value for zinc (an element of both anthropogenic and natural origin) is $55 \mathrm{mg} / \mathrm{kg}$, while the maximum and the minimum values were $167 \mathrm{mg} / \mathrm{kg}$ (sample 13) and $13 \mathrm{mg} / \mathrm{kg}$ (sample 1), respectively (see Table 2). The average value of copper is $36 \mathrm{mg} / \mathrm{kg}$, presenting the maximum value in sample $13(119 \mathrm{mg} / \mathrm{kg})$ and the minimum in sample 1 (12 $\mathrm{mg} / \mathrm{kg}$ ); the increased value of $\mathrm{Cu}$ in sample 13, taken for a small shelter with water depth $<2 \mathrm{~m}$, may be attributed to the use of $\mathrm{Cu}$-based antifouling agents in boats and fishing nets. The lowest lead value exhibits in sample $1(4 \mathrm{mg} / \mathrm{kg})$ and the highest in the sample $18(73 \mathrm{mg} / \mathrm{kg})$, with average value being equal to $26.1 \mathrm{mg} / \mathrm{kg}$. For nickel, the highest value $(95 \mathrm{mg} / \mathrm{kg})$ is found in sample 19, which presents also the maximum value for $\mathrm{Mn}(456 \mathrm{mg} / \mathrm{kg})$ and $\mathrm{Cr}(237 \mathrm{mg} / \mathrm{kg})$; these increased values could be attributed to the operation of the nearby electric power plant. Aluminium presents its maximum value in sample $9(47.1 \mathrm{mg} / \mathrm{kg})$, while the iron in sample $8(25.5$ $\mathrm{mg} / \mathrm{kg}$ ); these values are most likely related to harbour activity.

Table 1 - Gravel (G), sand (S), silt (Z) and clay (C) percentages and sediment texture of the seabed samples.

\begin{tabular}{|c|c|c|c|c|c|c|c|c|c|c|c|c|}
\hline Station & $\mathbf{1}$ & $\mathbf{2}$ & $\mathbf{3}$ & $\mathbf{4}$ & $\mathbf{5}$ & $\mathbf{6}$ & $\mathbf{7}$ & $\mathbf{8}$ & $\mathbf{9}$ & $\mathbf{1 0}$ & $\mathbf{1 1}$ & $\mathbf{1 2}$ \\
\hline $\mathrm{G}$ & 0.40 & 1.89 & 2.05 & 1.10 & 2.84 & 7.55 & 11.74 & 0.71 & 2.75 & 1.71 & 1.11 & 1.11 \\
\hline $\mathrm{S}$ & 99.59 & 32.21 & 39.55 & 21.2 & 50.66 & 27.45 & 31.66 & 25.49 & 21.45 & 49.31 & 52.99 & 98.31 \\
\hline $\mathrm{Z}$ & 0.01 & 52.69 & 41.27 & 62.13 & 37.96 & 48.86 & 36.42 & 54.7 & 59.31 & 40.62 & 35.04 & 0.58 \\
\hline C & 0.00 & 13.21 & 17.13 & 15.57 & 8.54 & 16.14 & 20.18 & 19.1 & 16.49 & 8.36 & 10.86 & 0.00 \\
\hline Text. & $(\mathrm{g}) \mathrm{S}$ & $(\mathrm{g}) \mathrm{sM}$ & $(\mathrm{g}) \mathrm{sM}$ & $(\mathrm{g}) \mathrm{sM}$ & $(\mathrm{g}) \mathrm{mS}$ & $\mathrm{gM}$ & $\mathrm{gM}$ & $(\mathrm{g}) \mathrm{sM}$ & $(\mathrm{g}) \mathrm{sM}$ & $(\mathrm{g}) \mathrm{mS}$ & $(\mathrm{g}) \mathrm{mS}$ & $(\mathrm{g}) \mathrm{S}$ \\
\hline Station & $\mathbf{1 3}$ & $\mathbf{1 4}$ & $\mathbf{1 5}$ & $\mathbf{1 6}$ & $\mathbf{1 7}$ & $\mathbf{1 8}$ & $\mathbf{1 9}$ & $\mathbf{2 0}$ & $\mathbf{2 1}$ & $\mathbf{2 2}$ & $\mathbf{2 3}$ & \\
\hline $\mathrm{G}$ & 14.89 & 4.45 & 6.25 & 4.76 & 0 & 3.81 & 0.86 & 11.71 & 0.74 & 49.49 & 2.00 & \\
\hline $\mathrm{S}$ & 17.94 & 45.9 & 42.1 & 70.14 & 99.98 & 53.96 & 58.06 & 87.98 & 99.05 & 50.51 & 37.63 & \\
\hline Z & 55.49 & 36.00 & 38.93 & 19.84 & 0.02 & 33.18 & 31.48 & 0.31 & 0.21 & 0.00 & 47.44 & \\
\hline C & 11.68 & 13.65 & 12.72 & 5.26 & 0.00 & 9.05 & 9.60 & 0.00 & 0.00 & 0.00 & 12.93 & \\
\hline Text & $\mathrm{Gm}$ & $(\mathrm{g}) \mathrm{sM}$ & $\mathrm{gM}$ & $(\mathrm{g}) \mathrm{mS}$ & $\mathrm{S}$ & $(\mathrm{g}) \mathrm{mS}$ & $(\mathrm{g}) \mathrm{mS}$ & $\mathrm{gS}$ & $(\mathrm{g}) \mathrm{S}$ & $\mathrm{sG}$ & $(\mathrm{g}) \mathrm{sM}$ & \\
\hline
\end{tabular}

Key. (g)S: slightly gravely Sand; (g)sM: slightly gravely sandy Mud; (g)mS: slightly gravelly muddy Sand; gM: gravelly Mud; (g)S: slightly gravelly Sand, Gm: muddy Gravel; gS: gravelly Sand; sG: sandy Gravel.

TOC ranged from $0.1 \%$ to $6.9 \%$, with its maximum value found in sample 13 ; the latter may be due to increased seaweed presence and/or to the influence of the nearby waste water treatment outfall. Finally, $\mathrm{CaCO}_{3}$ ranges from $17 \%$ (sample 12) to $67 \%$ (sample 11), being associated with the coarser grained samples and the presence of shell fragments.

The examined chemical element average values of the Chios Harbour coastal area are relatively lower compared to the other coastal areas of Greece (presented in table 3), with minor exceptions of $\mathrm{Cu}$ (due to the existence of small shelters and the main harbor) and $\mathrm{Cr}$ (due to the electric power plant).

According to geoaccumulation (Igeo) and combined contamination index (W), the sediments are characterized as either unpolluted or slightly polluted (Table 4), although there are some samples considered as polluted according to the Igeo index for specific trace metals (indicatively mentioned sample 2 and 13 for $\mathrm{Cu}$ and sample 8 for $\mathrm{Ni}$ ). Moreover, according the modified 
contamination degree $(\mathrm{mCd})$, the samples are characterised as low to very low polluted, with the exception of stations 2 and 19 that present a moderate degree of pollution (see table 4).

Table 2 - Metal / trace metals concentrations and percentages of $\mathrm{CaCO}_{3}$ and total organic carbon (TOC) of the seabed samples.

\begin{tabular}{|c|c|c|c|c|c|c|c|c|c|c|}
\hline \multirow[b]{2}{*}{ 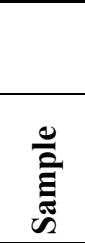 } & \multicolumn{8}{|c|}{$\begin{array}{l}\text { CONCETRATIONS IN TOTAL FRACTION } \\
\text { (mg/kg) }\end{array}$} & \multirow{2}{*}{$\begin{array}{l}0 \\
0 \\
0 \\
0 \\
0 \\
0\end{array}$} & \multirow{2}{*}{$\begin{array}{l}0 \\
\stackrel{0}{ } \\
\partial^{\circ}\end{array}$} \\
\hline & $\mathrm{Zn}$ & $\mathbf{C u}$ & Mn & $\mathbf{P b}$ & $\mathrm{Cr}$ & $\mathbf{N i}$ & $\begin{array}{r}\mathbf{F e} \\
\mathbf{x 1 0 ^ { 3 }}\end{array}$ & $\begin{array}{c}\text { Al } \\
\mathbf{x} 10^{3}\end{array}$ & & \\
\hline 01 & & & & & & 47.9 & & & 20 & \\
\hline 02 & & & & & & & & & & \\
\hline 03 & & & & & & & & & & \\
\hline 04 & 1 & & & & & & & & & \\
\hline 05 & 32.7 & & & & & 25.0 & & & & 0.0 \\
\hline 06 & 37.3 & 24.7 & & & & 3.6 & & & 3. & 3.2 \\
\hline 07 & 38.1 & & & & & 5.6 & & & 28 & 0.1 \\
\hline 08 & & & & & & & & & 23 & \\
\hline 09 & & & & & & & & & 27 & 1.1 \\
\hline 11 & 26. & & & & & & & & 67 & 2.4 \\
\hline 12 & 73.8 & & 2 & & & 26.5 & 22 & 42. & 17 & $\overline{0.3}$ \\
\hline 13 & 166.6 & 9.1 & & & & 61.9 & & 3 & 23 & 6.9 \\
\hline 15 & 33.4 & 22. & & \begin{tabular}{|l|l|}
6.9 \\
\end{tabular} & 106.4 & 61.8 & 15.0 & 28.9 & 35 & 2.9 \\
\hline 18 & 30. & & 181.7 & 72.8 & & 44.3 & 13. & 31 & 18 & 1 \\
\hline 19 & 27.6 & & & 8. & & 95.0 & & 36 & 30 & 0.3 \\
\hline 23 & 44.1 & & & 31. & & & & 36 & 30 & 1.5 \\
\hline 7 & 54.5 & 35.8 & 204.1 & 26. & 93. & 47.8 & 18. & 36.1 & 29 & 1.8 \\
\hline
\end{tabular}

Note: shaded are the samples from the Chios harbour basin

Table 3 - Concentrations of chemical in elements, in different Greek coastal areas.

\begin{tabular}{|c|c|c|c|c|c|c|}
\hline \multirow{2}{*}{ AREA } & \multirow{2}{*}{ References } & \multicolumn{5}{|c|}{ Element (mg/kg) } \\
\hline & & $\mathbf{Z n}$ & $\mathbf{C u}$ & $\mathbf{P b}$ & $\mathbf{N i}$ & $\mathrm{Cr}$ \\
\hline S. Evoikos Gulf & \multirow{6}{*}{ Anagnostou et al. (1998) } & 111 & 17 & 36 & 308 & 378 \\
\hline Elefsina & & 523 & 99 & 194 & 118 & 181 \\
\hline Maliakos & & 89 & 41 & & 234 & \\
\hline Pagasitikos & & 172 & 72 & 60 & 174 & 401 \\
\hline Thermaikos & & 158 & 43 & 190 & 106 & 190 \\
\hline Thessaloniki & & 296 & 79 & 64 & 95 & 221 \\
\hline NW Saronikos & Paraskevopoulou (2009) & 74 & 23 & 31 & 882 & 2911 \\
\hline Isthmia-Kehries & Dima (2000) & 180 & 28 & 29 & 421 & \\
\hline W. Saronikos & \multirow{5}{*}{ Giannopoulou (2005) } & 134 & 24 & 38 & 277 & 154 \\
\hline Elefsina & & 647 & 108 & 128 & 112 & 91 \\
\hline Psitaleia & & 460 & 124 & 138 & 150 & 122 \\
\hline E. Saronikos & & 436 & 86.5 & 86 & 93 & 157 \\
\hline S.Saronikos & & 164 & 23 & 49 & 92 & 80 \\
\hline Oropos & Botsou (2007) & 72 & 68 & 27 & 453 & 309 \\
\hline N. Aegean Sea & Karageorgis et al.(2005 a, b) & 231 & 55 & 141 & 221 & 249 \\
\hline Average of all areas above & & 250 & 57 & 86 & 250 & 420 \\
\hline Chios (east coast) & This study & 54.5 & 35.8 & 26.1 & 47.8 & 93.1 \\
\hline
\end{tabular}

$\underline{\text { XLVII, No } 3-1586}$ 
The percent incidence of adverse biological effects related to concentration, ranges according to TEL, PEL (Macdonald et al., (1996): table 3 p. 266) and ERM, ERL (Long et al., (1995): table 3 p. 92) guideline values are generally in low levels (Table 5). Specifically, according to TEL, PEL range of values, higher possibilities of adverse biological effects have $\mathrm{Cr}(53 \%)$ and $\mathrm{Cu}(56 \%)$, lower $\mathrm{Pb}(26 \%)$ and below $10 \% \mathrm{Ni}(9.6 \%)$ and $\mathrm{Zi}(4 \%)$. Moreover, according to ERM, ERL range of values, the largest possibility of harmful effects on living organisms is related to $\mathrm{Zn}(47 \%)$, and to a lesser degree to $\mathrm{Pb}(35.8 \%), \mathrm{Cu}(29.1 \%), \mathrm{Cr}(21.1 \%)$ and $\mathrm{Ni}(16.7 \%)$.

Table 4 - Environmental status of seabed sediments, according to Geoaccumulation Index (Igeo), modified Contamination degree (mCd) and Combined Contamination index (W).

\begin{tabular}{|c|c|c|c|c|c|c|c|}
\hline \multicolumn{6}{|c|}{ Igeo } & \multirow[t]{2}{*}{ mCd } & \multirow[t]{2}{*}{$\mathbf{W}$} \\
\hline Stat. & $\mathrm{Cr}$ & $\mathrm{Cu}$ & $\mathbf{N i}$ & $\mathbf{P b}$ & Zn & & \\
\hline 01 & UP & UP & SP & UP & UP & very low & UP \\
\hline 02 & SP & $\mathrm{P}$ & SP & UP & UP & moderate & SP \\
\hline 03 & SP & UP & SP & UP & UP & very low & UP \\
\hline 04 & SP & $\mathrm{P}$ & SP & UP & UP & low & UP \\
\hline 05 & SP & UP & UP & UP & UP & very low & UP \\
\hline 06 & SP & SP & $\mathrm{P}$ & UP & UP & very low & UP \\
\hline 07 & SP & SP & UP & UP & UP & very low & UP \\
\hline 08 & SP & SP & $\mathrm{P}$ & UP & UP & Low & SP \\
\hline 09 & SP & $\mathrm{P}$ & UP & UP & UP & Low & SP \\
\hline 11 & SP & UP & UP & UP & UP & very low & UP \\
\hline 12 & SP & UP & UP & UP & UP & very low & UP \\
\hline 13 & SP & HP & $\mathrm{P}$ & SP & UP & voderate & UP \\
\hline 15 & SP & UP & $\mathrm{P}$ & UP & UP & very low & UP \\
\hline 18 & SP & UP & SP & SP & UP & very low & SP \\
\hline 19 & $\mathrm{P}$ & SP & $\mathrm{P}$ & UP & UP & moderate & SP \\
\hline 23 & SP & SP & SP & UP & UP & very low & SP \\
\hline
\end{tabular}

\section{Conclusions}

The broader coastal area of Chios harbour consists of fine grained sediment that are generally characterized as slightly gravelly sandy mud ((g)sM), according to Folk (1974). The concentrations of the identified heavy metals $\mathrm{Zn}, \mathrm{Cu}, \mathrm{Pb}, \mathrm{Ni}, \mathrm{Fe}, \mathrm{Mn}, \mathrm{Al}, \mathrm{Cr}$, as well as those of TOC and $\mathrm{CaCO}_{3}$ vary within normal ranges, while their comparison with other Greek coastal areas showed that the study area is less polluted, although some metals' slightly increased values are found locally; the latter are related to the harbour of Chios, fishing shelters, the offshore area close to the electric power plant and nearby the outflow of the waste treatment plant.

The application of Igeo, $\mathrm{mCd}$ and $\mathrm{W}$ indices, showed that in most locations the bottom sediments are non-polluted, while marginally to slightly polluted found most of the samples in chromium, samples 2, 4, 6, 8, 19 \& 23 both in copper and in nickel, sample 7 only in copper, samples 1, 3, 13, $15,18 \& 19$ in nickel and samples $13 \& 18$ in lead. Nevertheless, all samples appeared not to have any significant environmental impact to benthic organisms, according to TEL, PEL and REM, ERL guideline values. 
Table 5 - Percent incidence of adverse biological effects, in concentration ranges, according to TEL - PEL) (Macdonald et al., 1996) and ERM - ERL guidelines values (Long et al., 1995).

\begin{tabular}{|c|c|c|c|c|c|c|c|c|c|c|}
\hline & \multicolumn{9}{|c}{ TEL - PEL } & \multicolumn{6}{c|}{ ERM- ERL } \\
\hline & $\mathbf{C r}$ & $\mathbf{C u}$ & $\mathbf{N i}$ & $\mathbf{P b}$ & $\mathbf{Z n}$ & $\mathbf{C r}$ & $\mathbf{C u}$ & $\mathbf{N i}$ & $\mathbf{P b}$ & $\mathbf{Z n}$ \\
\hline $\mathbf{1}$ & 4 & 9 & 9.4 & 6 & 4 & 2.9 & 2.9 & 16.7 & 8 & 6.1 \\
\hline $\mathbf{2}$ & 15 & 22 & 9.8 & 6 & 4 & 21.1 & 29.1 & 16.9 & 8 & 6.1 \\
\hline $\mathbf{3}$ & 15 & 9 & 8.4 & 6 & 4 & 2.9 & 2.9 & 16.7 & 35.8 & 6.1 \\
\hline $\mathbf{4}$ & 15 & 22 & 8.4 & 26 & 4 & 21.1 & 29.1 & 16.7 & 35.8 & 6.1 \\
\hline $\mathbf{5}$ & 4 & 9 & 8.4 & 6 & 4 & 2.9 & 2.9 & 16.7 & 8 & 6.1 \\
\hline $\mathbf{6}$ & 15 & 22 & 9.4 & 6 & 4 & 21.1 & 2.9 & 16.9 & 8 & 6.1 \\
\hline $\mathbf{7}$ & 15 & 22 & 8.4 & 6 & 4 & 21.1 & 29.1 & 16.7 & 8 & 6.1 \\
\hline $\mathbf{8}$ & 15 & 22 & 9.4 & 6 & 4 & 21.1 & 2.9 & 16.9 & 8 & 6.1 \\
\hline $\mathbf{9}$ & 15 & 22 & 8.4 & 26 & 4 & 21.1 & 29.1 & 1.9 & 8 & 6.1 \\
\hline $\mathbf{1 1}$ & 15 & 9 & 8.4 & 6 & 4 & 2.9 & 2.9 & 16.7 & 8 & 6.1 \\
\hline $\mathbf{1 2}$ & 4 & 22 & 8.4 & 6 & 4 & 2.9 & 2.9 & 16.7 & 8 & 6.1 \\
\hline $\mathbf{1 3}$ & 15 & 56 & 9.4 & 6 & 4 & 21.1 & 29.1 & 16.9 & 8 & 6.1 \\
\hline $\mathbf{1 5}$ & 15 & 22 & 9.4 & 6 & 4 & 21.1 & 2.9 & 16.9 & 8 & 6.1 \\
\hline $\mathbf{1 8}$ & 15 & 9 & 9.4 & 26 & 4 & 21.1 & 2.9 & 16.7 & 35.8 & 6.1 \\
\hline $\mathbf{1 9}$ & 53 & 22 & 9.5 & 6 & 4 & 21.1 & 2.9 & 16.9 & 8 & 6.1 \\
\hline $\mathbf{2 3}$ & 15 & 22 & 9.6 & 26 & 4 & 21.1 & 2.9 & 16.7 & 35.8 & 47 \\
\hline
\end{tabular}

\section{Acknowledgements}

The authors A. Tsoutsia, V. Kapsimalis and S. Poulos, during this work have been supported also by the Project MARE (MIS 375655), funded by the Operational Programme: "Education and lifelong learning, 2007-2013" of the Ministry of Education and Religious Affairs, Culture and Sports, co-funded by the European Union and the Greek Government. Mrs A. Tsoutsia was supported, also, by Papadakis Antonios Legacy. Finally, thanks are extended to Dr I. Panagiotopoulos (HCMR), Mr G. Pappas (HCMR) and to Mr. S. Petrakis (PhD candidate of University of Athens) for their contribution during the field trip and laboratory analyses.

\section{References}

Abrahim G.M.S. and Parker R.J. 2008. Assessment of heavy metal enrichment factors and the degree of contamination in marine sediments from Tamaki Estuary. Auckland. New Zealand, Environ Monitor Assess., 136(1-3), 227-238.

Anagnostou Ch., Kaberi H., and Karageorgis A. 1998. Horizontal and vertical distribution of heavy metal in sediments from Thermaikos Gulf, Rapp. Comm. Int. Mer Medit., 35, 222223.

Bornovas J. and Rondogianni-Tsiambaou Th. 1989. Geological map of Chios Island, Institute of Geology and Mineral Exploration (IGME).

Botsou F. 2007. Study on the impact of ephemeral rivers to the coastal marine environment: The case of Asopos River. Central Greece, Unpublished PhD Thesis in Chemical Oceanography, Faculty of Chemistry, University of Athens, 317 p. (in Greek). 
Clark R.B. 1993. Marine Pollution, $3^{\text {rd }}$ ed., Oxford University Press, 172 p.

Dima Th. 2000. Environmental characteristics of the NW Saronic Gulf, MSc Thesis in Environmental Chemistry and Technology, Faculty of Chemistry, University of Athens, 214 p. (in Greek).

Förstner U., Ahlf W., Calmano W. and Kersten M. 1990. Sediment criteria development Contributions from environmental geochemistry to water quality management, (In:) D. Heling. P. Rothe. U. Förstner. \& P. Stoffers (eds) Sediments and environmental geochemistry: Selected aspects and case studies. Springer, Berlin Heidelberg, 311-338.

Giannopoulou K. 2005. Heavy metals in the sediments and the waters of Saronikos gulf for the year 2004, MSc Thesis in Environmental Chemistry and Technology, Faculty of Chemistry, University of Athens, 144p. (in Greek).

Karageorgis A.P., Anagnostou C.L. and Kaberi H. 2005a. Geochemistry and mineralogy of the NW Aegean Sea surface sediments: implications for river runoff and anthropogenic impact, Cont. Shelf Res., 20(1), 69-88.

Karageorgis A.P., Kaberi H., Price N.B., Muir G.K.P., Pates J.M. and Lykousis V. 2005 b. Chemical composition of short sediment cores from Thermaikos Gulf (Eastern Mediterranean): Sediment accumulation rates. Trawling and winnowing effects, Cont. Shelf Res, 25(19-20), 2456-2475.

Long E.R., MacDonald D.D. Smith S.L. and Calder F.D. 1995. Incidence of Adverse Biological Effects Within Ranges of Chemical Concentrations in Marine and Estuarine Sediments, Envir. Manag., 19(1), 81-97.

Müller G. 1969. Index of geo-accumulation in sediments of the Rhine River. Geoj. J., 2(3), 108118.

Macdonald D.D., Scott C.R., Calder D.F., Long R. E. and Ingersoll G.C. 1996. Development and evaluation of sediment quality guidelines for Florida coastal waters, Ecotoxicology, 5, 253278.

Paidas M.G. 2011. Water resources in Chios Island, MSc Thesis, National Technical University of Athens (in Greek).

Paraskevopoulou V. 2009. Distribution and chemical behaviour of heavy metals in sea area affected by industrial pollution (NW Saronikos), Unpublished PhD Thesis, Faculty of Chemistry, University of Athens, 288p. (in Greek).

Poulos S. G., Alexandrakis G., Karditsa A. and Drakopoulos P. 2007. Heavy metals investigation, as pollutant indicators. in bottom sediments. in the harbours Heraklion and Alexandroupolis (Aegean Sea. Greece), Proceedings of the $10^{\text {th }}$ International Conference on Environmental Science and Technology (CEST), Kos island, Greece, 5-7/9/2007, B634-B641.

Robertson A.H.F. and Ustaömer T. 2009. Upper Palaeozoic subduction/accretion processes in the closure of Palaeotethys: Evidence from the Chios Melange (E. Greece). The Karaburun Melange (W. Turkey) and the Teke Dere Unit (SW Turkey), Sedim. Geol., 220, 29-59.

Tsoutsia I.A. 2012. Environmental study of surficial seabed sediments of the wider area of port of Chios Island, Unpublished MSc Thesis, University of Athens, Scholl of Science (in Greek), $192 \mathrm{p}$.

Walkley A. and Black I.A. 1934. An examination of the Degtjareff method for determining organic carbon in soils: effect of variations in digestion conditions and of inorganic soil constituents, Soil Sc., 37(1), 29-37.

Widianarko B., Van Gestel C.A.M., Verweij R.A. and Van Straalen N.M. 2000. Associations between trace metals in sediment water and guppy. Poecilia reticulata (Peters) from urban streams of Semarang, Indonesia, Ecotox. Envir. Saf., 46(1), 101-107. 